\title{
An Efficient and Environmentally Benign Chemical Synthesis of Testolactone
}

\section{Juan Zinczuk, José A. Bacigaluppo, María I. Colombo, Raquel M. Cravero, Manuel González-Sierra and Edmundo A. Rúveda*}

\author{
Instituto de Química Orgánica de Síntesis (CONICET-UNR), Facultad de Ciencias Bioquímicas y Farmacéuticas, \\ Suipacha 531, 2000 Rosario, Argentina
}

\begin{abstract}
Um estudo comparativo é descrito para dois ensaios da síntese do esteróide testolactona de interesse biológico. O primeiro ensaio é clássico e eficiente. No segundo ensaio reagentes de risco foram substituídos por alternativos não perigosos, mantendo-se o mesmo grau de eficiência.
\end{abstract}

A comparative study of two approaches for the chemical synthesis of the biologically interesting steroid testolactone is described. The first approach is efficient but classical, in the second one, hazardous chemicals were replaced by benign alternatives maintaining the same degree of efficiency.

Keywords: testolactone, green chemistry, $o$-iodoxybenzoic acid (IBX)

\section{Introduction}

Testolactone (1) was one of the first steroids used in the clinical treatment of breast cancer and was withdrawn from the market a few years ago. More recently its activity as an aromatase inhibitor has been established ${ }^{1}$ and this fact prompted us to look into its synthesis.<smiles></smiles>

Testolactone was obtained commercially by microbial transformation of either testosterone or progesterone and also synthetically, albeit in low yield. ${ }^{2}$ The only chemical synthesis of $\mathbf{1}$ so far described in the literature starting from dehydroepiandrosterone (2) is shown in Scheme $1 .^{3}$ The strategy followed in this synthetic approach consisted in the initial formation of the lactone ring by a BaeyerVilliger oxidation with peracetic acid of ring $\mathrm{D}$ of the protected derivative $\mathbf{3}$, followed by the introduction of the additional double bond in the ring A of intermediate 5 by selenium dioxide oxidation.

Our first approach was a rather direct and classical one, our main concern was to achieve a more efficient synthetic

\footnotetext{
* e-mail: eruveda@fbioyf.unr.edu.ar

This paper is dedicated to Prof. Albert J. Kascheres on occasion of his $60^{\text {th }}$ birthday
}

route. However, we then began to consider the idea of replacing hazardous chemicals by more benign alternatives hoping to maintain the same degree of efficiency.

\section{Results and Discussion}

We initiated our project on the chemical synthesis of testolactone (1) by focusing our attention on the generation of the dienone system at the beginning of the sequence and leaving, the formation of the lactone ring, for the last step. Our first objective was then the preparation of androsta-1,4-dien-3,17-dione (8). We envisaged that because of the low electrophilicity of the doubly conjugated carbonyl group at ring A of $\mathbf{8}$ the attack of the peracid would occur preferentially at the C-17 carbonyl.

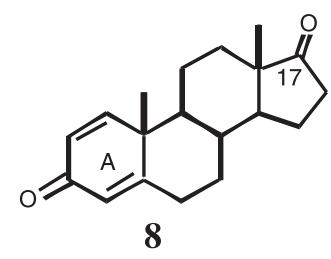

Compound $\mathbf{8}$ has been prepared long time ago by Djerassi and Scholz. ${ }^{4}$ by the sequence of brominationdehydrobromination of the saturated steroid androstane3,17-dione and, more recently, testosterone itself was oxidized with selenium dioxide to the corresponding 1,4diene derivative. ${ }^{5}$

For the preparation of $\mathbf{8}$ (Scheme 2) we started with testosterone propionate (6a) which, upon saponification 


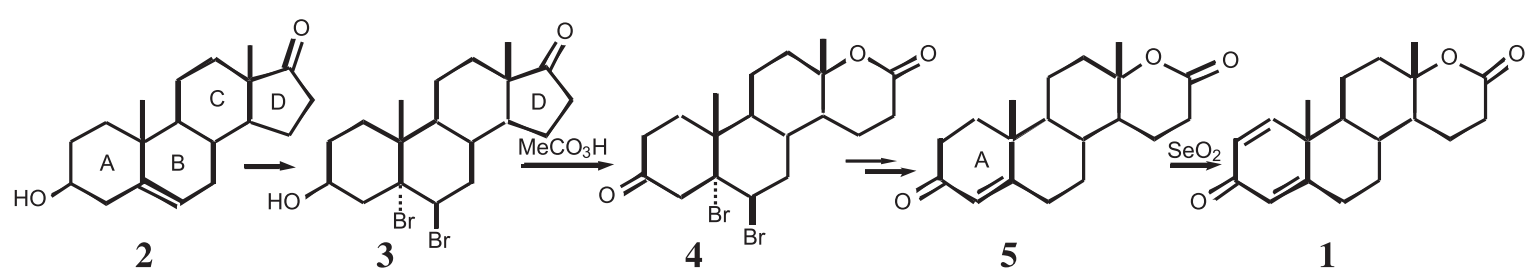

Scheme 1.

with potassium hydroxide in refluxing ethanol, followed by oxidation with PCC on silica gel in dichloromethane at room temperature ${ }^{6}$ afforded androsta-4-en-3,17-dione (7) in good overall yield. For the introduction of the 1,4diene system into the A-ring of $\mathbf{7}$, we decided to use the one-pot operation employing 2,3-dichloro-5,6-dicyanobenzoquinone (DDQ). ${ }^{7}$ DDQ has been extensively employed in steroid chemistry avoiding the use of halogens and selenium reagents. ${ }^{8}$ We choose to use DDQ over the palladium-catalyzed process to dehydrogenate carbonyl enol ethers ${ }^{9}$ because we found the one-pot DDQ procedure to be more chemoselective. In practice, the treatment of $\mathbf{7}$ with DDQ in the presence of benzoic acid in refluxing toluene, afforded $\mathbf{8}$ in $60 \%$ yield after recrystallization. With $\mathbf{8}$ in hand we studied the formation of the lactone ring present in $\mathbf{1}$. Here we decided to look for alternatives to the use of the potentially hazardous peracetic acid as oxidizing agent. The best result was obtained by using the safer and inexpensive monoperoxyphthalic acid magnesium salt hexahydrate (MMPP), ${ }^{10}$ giving $98 \%$ yield of testolactone (1). As we had anticipated, no isomeric lactones were detected in the reaction mixture, indicating that the attack of the peracid occurred exclusively at the C-17.

Alternatively, compound $\mathbf{8}$ can be also prepared from testosterone propionate (6a) (Scheme 3) which, on treatment with DDQ in the presence of benzoic acid in toluene at $90{ }^{\circ} \mathrm{C}$ for $16 \mathrm{~h}$, afforded $9 \mathrm{a}$ in $85 \%$ yield. Saponification of $9 \mathbf{a}$ with potassium carbonate in methanol followed by oxidation with Jones reagent produced $\mathbf{8}$ in good overall yield.
The recent publication of Nicolaou et al. ${ }^{11}$ on the use of $o$-iodoxybenzoic acid (IBX) as a highly efficient agent for the dehydrogenation of carbonyl compounds and its capability to accomplish in the same pot multiple oxidations, prompted us to re-examine our sequences toward testolactone (1). By oxidation with IBX, testosterone (6b) could be transformed directly into androst-1,4-dien-3,17dione (8), in a chromium-free process and avoiding the use of DDQ (which is known for its toxicity). Furthermore, IBX is nontoxic and is prepared from a nontoxic and cheap commercial product (o-iodobenzoic acid) in an environmentally clean way. Although IBX was reported to be explosive it was shown that by using oxone in its preparation the risks posed by contaminants are eliminated. ${ }^{12,13}$ According to Nicolaou et al. ${ }^{11}$ many experiments were carried out in homogeneous conditions at temperatures between $45-90^{\circ}$ on multigram scales without any incidents. In practice, the treatment of testosterone $(\mathbf{6 b})$ with IBX in DMSO ${ }^{14}$ solution at $85^{\circ} \mathrm{C}$ for $24 \mathrm{~h}$ afforded 8 in $58 \%$ yield. Unfortunately, the sequence requires a chromatographic purification in order to obtain a good quality product. On the other hand, the oxidation of testosterone propionate (6a) (Scheme 3), under the same reaction conditions, gave $\mathbf{9 a}$ which, on saponification with potassium carbonate in methanol, followed by a second oxidation with IBX at room temperature, afforded $\mathbf{8}$ in $c a .70 \%$ overall yield and pure enough as to complete the synthesis of testolactone (1) (Scheme 3).

Taken together, these observations show that by using reagents like IBX and MMPP, we come up with an efficient and environmentally benign chemical synthesis of the

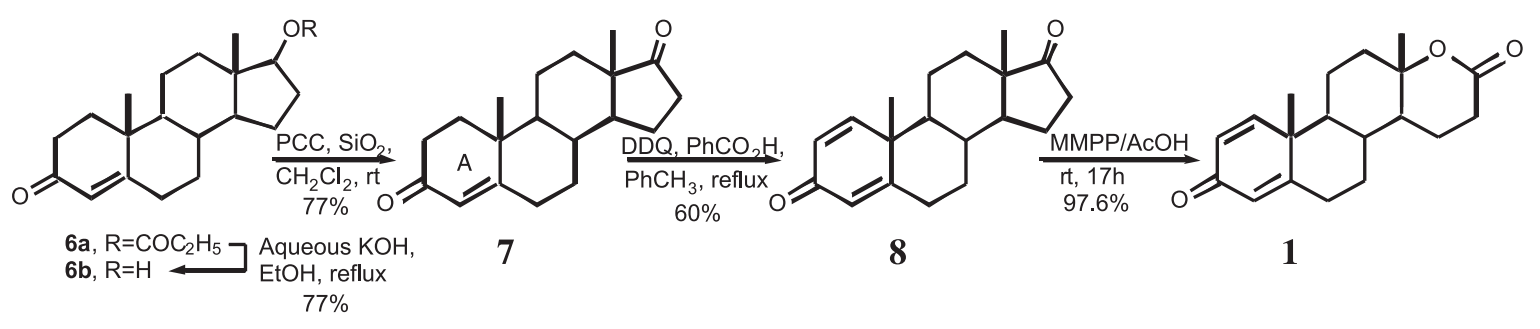

Scheme 2. 

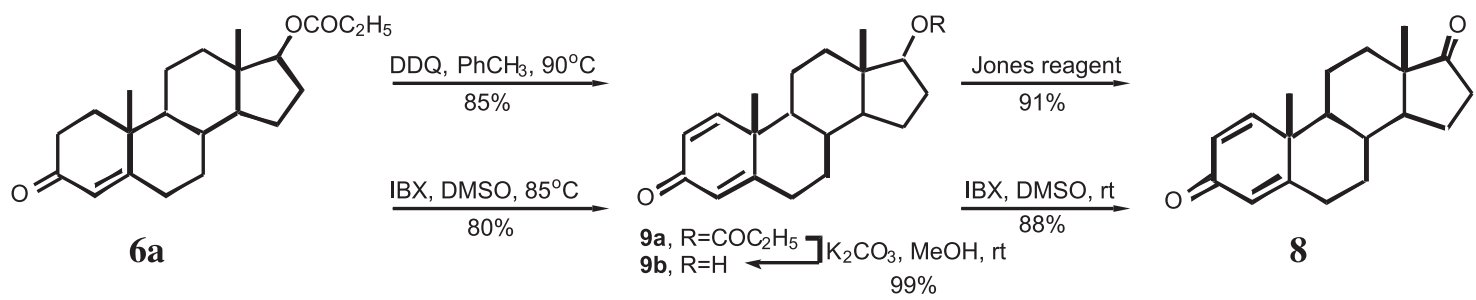

Scheme 3.

biologically active compound testolactone (1). It is interesting to mention that these observations together with the recent report on polymer-supported IBX ${ }^{15}$ could be useful to develop green sequences toward biologically active steroids.

\section{Experimental}

Melting points are uncorrected. IR spectra were measured in a Bruker FT-IFS 25 spectrometer in $\mathrm{KBr}$ disks. The ${ }^{1} \mathrm{H}$ and ${ }^{13} \mathrm{C}$ NMR spectra were recorded on a Bruker AC 200 spectrometer for $\mathrm{CDCl}_{3}$ solutions with $\mathrm{Me}_{4} \mathrm{Si}$ as internal standard. Column chromatography was performed on silica gel $60 \mathrm{H}$, slurry packed, run under low pressure of nitrogen and employing increasing amounts of EtOAc in hexane as solvent. Analytical TLC was carried out using Kieselgel Merck $\mathrm{F}_{254}$ with thickness $0.20 \mathrm{~mm}$. The homogeneity of all intermediates prior to the highresolution mass spectral determination was carefully verified by TLC. All chemicals were used as purchased or purified according to standard procedure.

\section{Androst-1,4-dien-3,17-dione (8)}

To a stirred solution of testosterone propionate $(\mathbf{6 a})$ $(2.00 \mathrm{~g}, 5.82 \mathrm{mmol})$ in EtOH $(20 \mathrm{~mL}), \mathrm{KOH}(500 \mathrm{mg}$, $8.91 \mathrm{mmol}$ ) was added and the mixture was heated at reflux for $1 \mathrm{~h}$ until the TLC spot for the starting material had disappeared. The yellow mixture was poured into $\mathrm{H}_{2} \mathrm{O}(100$ $\mathrm{mL})$ and extracted with $\mathrm{Et}_{2} \mathrm{O}(3 \times 100 \mathrm{~mL})$. The combined organic extracts were washed with $\mathrm{H}_{2} \mathrm{O}(2 \times 40 \mathrm{~mL})$, brine $(40 \mathrm{~mL})$, dried $\left(\mathrm{Na}_{2} \mathrm{SO}_{4}\right)$ and evaporated. The residue $(1.66 \mathrm{~g})$ was recrystallized from acetone to yield pure testosterone (6b) (1.29 g, 77\%), mp 153.2-154.6 ${ }^{\circ} \mathrm{C}$; $[\alpha]_{\mathrm{D}}{ }^{24}+112.4(\mathrm{c}=4, \mathrm{EtOH})\left[\right.$ Lit. $^{16} \mathrm{mp} 155^{\circ} \mathrm{C} ;[\alpha]_{\mathrm{D}}{ }^{24}+109$ $(\mathrm{c}=4, \mathrm{EtOH})] ; \mathrm{IR}(\mathrm{KBr}) v_{\max } / \mathrm{cm}^{-1}: 3534,3386,2926,1666$, 1664, 1614; ' ${ }^{\mathrm{H}}$ NMR $\delta 0.79$ (s, 3H), 0.82-1.15 (m, 4H), $1.19(\mathrm{~s}, 3 \mathrm{H}), 1.22-2.20(\mathrm{~m}, 12 \mathrm{H}), 2.25-2.55(\mathrm{~m}, 4 \mathrm{H}), 3.65$ (dd, $J_{16 \alpha, 17} 7.9$ and $\left.J_{16 \beta, 17} 8.3 \mathrm{~Hz}, 1 \mathrm{H}\right), 5.72(\mathrm{br} \mathrm{s}, 1 \mathrm{H}) ;{ }^{13} \mathrm{C}$ NMR $\delta 10.85(\mathrm{q}), 17.18(\mathrm{q}), 20.42(\mathrm{t}), 23.11(\mathrm{t}), 30.13(\mathrm{t})$, $31.33(\mathrm{t}), 32.58(\mathrm{t}), 33.69(\mathrm{t}), 35.43(\mathrm{~d}), 35.48(\mathrm{t}), 36.22(\mathrm{t})$,
38.44 (s), 42.59 (s), 50.27 (d), 53.70 (d), 81.24 (d), 123.58 (d), 171.20 (s), 199.38 (CO).

A mixture of silica gel (70-230 mesh, $1.49 \mathrm{~g}$ ) and PCC $(1.49 \mathrm{~g}, 6.94 \mathrm{mmol})$ was ground to a fine powder using a mortar and a pestle. ${ }^{6}$ This light orange mixture was added to $\mathrm{CH}_{2} \mathrm{Cl}_{2}(16 \mathrm{~mL})$, while stirring the orange suspension, testosterone $(\mathbf{6 b})(1.00 \mathrm{~g}, 3.47 \mathrm{mmol})$ was added and the mixture was stirred at room temperature. After $2 \mathrm{~h}$ the reaction was completed (TLC). The reaction mixture was then filtered through a pad of Celite and silica gel and the precipitate was washed with $\mathrm{Et}_{2} \mathrm{O}(40 \mathrm{~mL})$ and a 1:1 mixture of $\mathrm{Et}_{2} \mathrm{O}$ $\mathrm{AcOEt}(80 \mathrm{~mL})$. Evaporation of the filtrate afforded a residue (923 mg) which was recrystallized from acetone to yield pure androst-4-ene-3,17-dione (7) (760 mg, 77\%), mp 173.5$174.3{ }^{\circ} \mathrm{C} ;[\alpha]_{\mathrm{D}}{ }^{24}+189,3$ (c=2, EtOH) $\left[\right.$ Lit. ${ }^{17} \mathrm{mp} 173-174{ }^{\circ} \mathrm{C}$, $\left.[\alpha]_{\mathrm{D}}^{24}+191(\mathrm{c}=4, \mathrm{EtOH})\right] ; \mathrm{IR}(\mathrm{KBr}) v_{\max } / \mathrm{cm}^{-1}: 2920,2840$, 1736, 1672; ${ }^{1} \mathrm{H}$ NMR $\delta 0.93$ (s, 3H), 0.95-1.40 (m, 4H), 1.22 (s, 3H), 1.45-2.30 (m, 11H), 2.40-2.60 (m, 4H), $5.75\left(\mathrm{~d}, J_{4,6}\right.$ $1.5 \mathrm{~Hz}, 1 \mathrm{H}) ;{ }^{13} \mathrm{C} N M R \delta 13.46(\mathrm{q}), 17.13(\mathrm{q}), 20.06(\mathrm{t}), 21.48$ $(\mathrm{t}), 30.50(\mathrm{t}), 31.04(\mathrm{t}), 32.31(\mathrm{t}), 33.66(\mathrm{t}), 34.88(\mathrm{~d}), 35.44(\mathrm{t}$, two carbons), 38.39 (s), 47.23 (s), 50.58 (d), 53.56 (d), 123.85 (d), 170.08 (s), 198.94 (CO), 220.00 (CO).

To a stirred solution of $7(500 \mathrm{mg}, 1.75 \mathrm{mmol})$ in toluene (40 mL), DDQ (500 mg, $2.20 \mathrm{mmol}$ ) and benzoic acid (355 mg, $2.9 \mathrm{mmol}$ ) were added. After $1 \mathrm{~h}$ of heating at reflux, an additional amount of DDQ (250 mg, $1.10 \mathrm{mmol})$ was added and the heating was continued for $2 \mathrm{~h}$. The mixture was cooled at $\mathrm{rt}$ and filtered. The precipitate was washed with toluene $(6 \mathrm{~mL})$ and the filtrate evaporated. The oily residue dissolved in $\mathrm{CH}_{2} \mathrm{Cl}_{2}$ was mixed with silica gel $(2.50 \mathrm{~g})$ and filtered through a bed of basic alumina $(3 \mathrm{~cm})$ with washings of a 8:2 mixture of hexane : EtOAc $(180 \mathrm{~mL})$. Evaporation of the filtrate afforded a crystalline residue (348 $\mathrm{mg}$ ), further washings with a 1:1 mixture of hexane : EtOAc $(100 \mathrm{~mL})$ gave an additional amount of crystalline residue $(57 \mathrm{mg})$. Recrystallization of the crude residue $(405 \mathrm{mg})$ from a mixture of diisopropyl etheracetone gave $8(300 \mathrm{mg}, 60 \%) \mathrm{mp} 141.0-142.4^{\circ} \mathrm{C}$; $[\alpha]_{\mathrm{D}}{ }^{24}+116.8\left(\mathrm{c}=2, \mathrm{CHCl}_{3}\right) ;\left[\right.$ Lit. $^{4} \mathrm{mp} 139-140{ }^{\circ} \mathrm{C}$; $[\alpha]_{\mathrm{D}}{ }^{24}+115.8\left(\mathrm{CHCl}_{3}\right]$; IR $(\mathrm{KBr}) v_{\max } / \mathrm{cm}^{-1}: 2926,2842$, $1738,1658,1622$; ${ }^{1} \mathrm{H}$ NMR $\delta 0.94$ (s, 3H), 1.00-1.30 (m, 
$3 \mathrm{H}), 1.25$ (s, 3H), 1.50-2.20 (m, 9H), 2.35-2.60 (m, 3H), $6.09\left(\mathrm{dd}, J_{2,4} 1.9\right.$ and $\left.J_{4,6} 1.5 \mathrm{~Hz}, 1 \mathrm{H}\right), 6.23\left(\mathrm{dd}, J_{1,2} 10.1\right.$ and $\left.J_{2,4} 1.9 \mathrm{~Hz}, 1 \mathrm{H}\right), 7.05\left(\mathrm{~d}, J_{1,2} 10.1 \mathrm{~Hz}, 1 \mathrm{H}\right) ;{ }^{13} \mathrm{C}$ NMR $\delta 13.12$ (q), $18.04(\mathrm{q}), 21.17(\mathrm{t}), 21.36(\mathrm{t}), 30.50(\mathrm{t}), 31.59(\mathrm{t}), 31.83$ (t), $34.28(\mathrm{~d}), 34.91(\mathrm{t}), 42.78(\mathrm{~s}), 46.92(\mathrm{~s}), 49.61(\mathrm{~d}), 51.57$ (d), 123.22 (d), 126.81 (d), 154.88 (d), 167.95 (s), 185.30 (CO), 219.09 (CO). HRMS calcd. for $\mathrm{C}_{19} \mathrm{H}_{24} \mathrm{O}_{2}\left(\mathrm{M}^{+}\right)$: 284.1776, found: 284.1772. Anal. Calcd. for $\mathrm{C}_{19} \mathrm{H}_{24} \mathrm{O}_{2}$ : C, 80.24; H, 8.51\%. Found: C, 80.38; H, 8.47\%.

\section{Testolactone (1)}

To a stirred solution of $\mathbf{8}(580 \mathrm{mg}, 2.04 \mathrm{mmol})$ in $\mathrm{AcOH}$ (3 mL) MMPP (80\%) (1.26 g, $2.04 \mathrm{mmol})$ was added and the mixture was stirred at $\mathrm{rt}$ for $17 \mathrm{~h}$ until TLC spot for the starting material had disappeared. The mixture was poured into brine and extracted with EtOAc. The combined organic extracts were washed with $\mathrm{H}_{2} \mathrm{O}$ and brine, dried $\left(\mathrm{Na}_{2} \mathrm{SO}_{4}\right)$ and evaporated to give $\mathbf{1}(598 \mathrm{mg}, 98 \%)$.

An analytically pure sample was obtained by crystallization from acetone, $\mathrm{mp} 217.2-219^{\circ} \mathrm{C} .[\alpha]_{\mathrm{D}}{ }^{19}-43.5$ $\left(\mathrm{c}=1, \mathrm{CHCl}_{3}\right)\left[\right.$ Lit. $^{2} \mathrm{mp} 218-219^{\circ} \mathrm{C} ;[\alpha]_{\mathrm{D}}-44(\mathrm{c}=1.29$, $\left(\mathrm{CHCl}_{3}\right)$. IR $(\mathrm{KBr}) v_{\max } / \mathrm{cm}^{-1}: 2955,1715,1660,1630,1605$, 1295, 1095, 895; ${ }^{1} \mathrm{H}$ NMR $\delta: 0.90-1.80(\mathrm{~m}, 8 \mathrm{H}), 1.21$ (s, $3 \mathrm{H}), 1.39$ (s, 3H), 1.85-2.20 (m, 4H), 2.40-2.80 (m, 3H), 6.10 (br s, $1 \mathrm{H}$ ), 6.27 (dd, $J 10.2$ and $1.9 \mathrm{~Hz}, 1 \mathrm{H}), 7.03$ (d, $J$ $10.2 \mathrm{~Hz}, 1 \mathrm{H}) ;{ }^{13} \mathrm{C}$ NMR $\delta: 18.48(\mathrm{q}), 19.91(\mathrm{q}), 19.91(\mathrm{t})$, $23.18(\mathrm{t}), 28.26(\mathrm{t}), 31.83(\mathrm{t}), 32.03(\mathrm{t}), 37.71(\mathrm{~d}), 38.69(\mathrm{t})$, 42.77 (s), 45.36 (d), 50.63 (d), 82.29 (s), 123.90 (d), 127.83 (d), 154.30 (d), 167.22 (s), 170.71 (CO), 185.78 (CO). HRMS calcd. for $\mathrm{C}_{19} \mathrm{H}_{24} \mathrm{O}_{3}\left(\mathrm{M}^{+}\right)$: 300.1726 , found: 300.1731. Anal. Calcd. for $\mathrm{C}_{19} \mathrm{H}_{24} \mathrm{O}_{3}: \mathrm{C}, 75.97 ; \mathrm{H}, 8.05 \%$. Found: C, 75.86; H, 8.00\%.

\section{Alternative preparation of compound 8}

To a stirred solution of testosterone propionate (6a) $(2.00 \mathrm{~g}, 5.81 \mathrm{mmol})$ in toluene $(150 \mathrm{~mL})$, DDQ $(1.96 \mathrm{~g}$, $8.63 \mathrm{mmol})$ and benzoic acid $(710 \mathrm{mg}, 5.81 \mathrm{mmol})$ were added. After $16 \mathrm{~h}$ of heating at $90^{\circ} \mathrm{C}$ (internal temperature) the reaction was completed (TLC). The cooled reaction mixture was then evaporated and dioxane $(15 \mathrm{~mL})$ was added. The precipitate that was separated by filtration, was washed with dioxane $(22 \mathrm{~mL})$ and the filtrate in turn, was chromatographed through neutral alumina ( $80 \mathrm{~g})$ with elution with ethyl acetate $(230 \mathrm{~mL})$. Evaporation of the solvent afforded 9a as solid (1.68 g, 85\%) that was used in the next step without further purification.

An analytically pure sample was obtained by crystallization from EtOH- $\mathrm{H}_{2} \mathrm{O}, \mathrm{mp} 140.2-141.1^{\circ} \mathrm{C} .[\alpha]_{\mathrm{D}}{ }^{24}$ 33.7 (c= 1, EtOH). IR (KBr) $v_{\max } / \mathrm{cm}^{-1}: 2960,1745,1675$,
$1635,1612,1195,890 ;{ }^{1} \mathrm{H}$ NMR $\delta 0.87(\mathrm{~s}, 3 \mathrm{H}), 1.14(\mathrm{t}, J$ $7.6 \mathrm{~Hz}, 3 \mathrm{H}), 1.00-1.30(\mathrm{~m}, 4 \mathrm{H}), 1.24(\mathrm{~s}, 3 \mathrm{H}), 1.35-1.85(\mathrm{~m}$, $7 \mathrm{H}), 1.90-2.05(\mathrm{~m}, 1 \mathrm{H}), 2.1-2.25(\mathrm{~m}, 1 \mathrm{H}), 2.28-2.58(\mathrm{~m}$, 2H), 2.33 (q, J 7.6 Hz, 2H), 4.60 (t, J 8.4 Hz, 1H), 6.08 (br s, $1 \mathrm{H}), 6.23$ (dd, $J 10.1$ and $1.9 \mathrm{~Hz}, 1 \mathrm{H}), 7.06(\mathrm{~d}, J 10.1 \mathrm{~Hz}$, $1 \mathrm{H}) ;{ }^{13} \mathrm{C}$ NMR $\delta 8.88(\mathrm{q}), 11.74(\mathrm{q}), 16.36(\mathrm{q}), 21.98(\mathrm{t})$, $23.28(\mathrm{t}), 27.07(\mathrm{t}), 27.35(\mathrm{t}), 32.33(\mathrm{t}), 32.70(\mathrm{t}), 34.90(\mathrm{~d})$, 36.15 (t), 42.38 (s), 43.14 (s), 49.51 (d), 51.88 (d), 81.88 (d), 123.48 (d), 127.10 (d), 155.37 (d), 166.58 (s), 173.98 (CO), $185.82(\mathrm{CO})$. HRMS calcd. for $\mathrm{C}_{22} \mathrm{H}_{30} \mathrm{O}_{3}\left(\mathrm{M}^{+}\right)$: 342.2195, found: 342.2200. Anal. Calcd. for $\mathrm{C}_{22} \mathrm{H}_{30} \mathrm{O}_{3}: \mathrm{C}$, 77.16; H, $8.83 \%$. Found: C, 77.18; H, 8.88\%.

To a stirred solution of $9 \mathrm{a}(1.68 \mathrm{~g}, 4.93 \mathrm{mmol})$ in $\mathrm{MeOH}$ $(25 \mathrm{~mL}) \mathrm{K}_{2} \mathrm{CO}_{3}(2.10 \mathrm{~g}, 15 \mathrm{mmol})$ was added and the mixture was stirred at $\mathrm{rt}$ for $10 \mathrm{~h}$ until TLC spot for the starting material had disappeared. The mixture was poured into brine and extracted with $\mathrm{Et}_{2} \mathrm{O}$. The combined organic extracts were washed with $\mathrm{H}_{2} \mathrm{O}$ and brine, dried $\left(\mathrm{Na}_{2} \mathrm{SO}_{4}\right)$ and evaporated to yield $9 \mathbf{b}(1.39 \mathrm{~g}, 99 \%)$ that was used in the next step without further purification.

An analytically pure sample was obtained by crystallization from EtOAc, mp 171.7-173.1 ${ }^{\circ} \mathrm{C} .[\alpha]_{\mathrm{D}}{ }^{19}+23.1$ $\left(\mathrm{c}=1, \mathrm{CHCl}_{3}\right) ;\left[\mathrm{Lit}^{5}{ }^{5} \mathrm{mp} 168-170{ }^{\circ} \mathrm{C} ;[\alpha]_{\mathrm{D}} 23\left(\mathrm{CHCl}_{3}\right)\right]$; IR (KBr) $v_{\text {max }} / \mathrm{cm}^{-1}: 3450,2845,1655,1611,1592,1401$, 1061,$881 ;{ }^{1} \mathrm{H}$ NMR $\delta 0.82$ (s, 3H), 0.85-1.15 (m, 4H), 1.24 (s, 3H), 1.30-2.15 (m, 10H), 2.20-2.60 (m, 2H), 3.60 (t, J 8.4 $\mathrm{Hz}, 1 \mathrm{H}), 6.07$ (br s, 1H), 6.23 (dd, $J 10.2$ and $1.9 \mathrm{~Hz}, 1 \mathrm{H}$ ), 7.05 (d, $J 10.2 \mathrm{~Hz}, 1 \mathrm{H}) ;{ }^{13} \mathrm{C}$ NMR $\delta: 10.98$ (q), 16.47 (q), $22.31(\mathrm{t}), 23.31(\mathrm{t}), 30.02(\mathrm{t}), 32.58(\mathrm{t}), 32.94(\mathrm{t}), 35.33(\mathrm{~d})$, 36.11 (t), 42.89 (s), 43.47 (s), 49.88 (d), 52.32 (d), 82.00 (d), 123.53 (d), 127.15 (d), 155.96 (d), 169.35 (s), 186.31 (CO); HRMS calcd. for $\mathrm{C}_{19} \mathrm{H}_{26} \mathrm{O}_{2}\left(\mathrm{M}^{+}\right)$: 286.1933, found: 286.1938. Anal. Calcd. for $\mathrm{C}_{19} \mathrm{H}_{26} \mathrm{O}_{2}$ : C, 79.68; H, $9.15 \%$. Found: C, 79.77; H, $9.15 \%$.

Jones reagent $(1.61 \mathrm{~mL})$ was added dropwise to a stirred solution of $9 \mathbf{b}(1.39 \mathrm{~g}, 4.85 \mathrm{mmol})$ in acetone $(32 \mathrm{~mL})$ at $0{ }^{\circ} \mathrm{C}$. After complete addition, the mixture was allowed to reach room temperature and stirred until the reaction reached completion as determined by the absence of starting material by TLC $(2 \mathrm{~h})$. The reaction was then quenched by the addition of a few drops of 2-propanol and the mixture was filtered through a pad of Celite and silica gel and the precipitate was washed with hexane $(100 \mathrm{~mL})$ and EtOAc $(300 \mathrm{~mL})$. Evaporation of the filtrate afforded androst-1,4-dien-3,17-dione (8) (1.26 g, 91\%). This product can be used in the next step without further purification.

\section{Preparation of $\boldsymbol{8}$ with IBX}

Oxidation of testosterone $(\boldsymbol{6} \boldsymbol{b})$. To a stirred solution of 
testosterone (6b) (144 mg, $0.5 \mathrm{mmol})$ in DMSO $(5 \mathrm{~mL})$ IBX $(1.12 \mathrm{~g}, 4 \mathrm{mmol})$ was added. After heating at $85^{\circ} \mathrm{C}$ for $24 \mathrm{~h}$ the reaction mixture was poured into EtOAc $(20 \mathrm{~mL})$ and the organic phase was washed with $\mathrm{H}_{2} \mathrm{O}, 5 \%$ aqueous $\mathrm{NaHCO}_{3}$ and brine, dried and evaporated to yield 8 (83 mg, $58 \%$ ). TLC analysis showed no starting material, however unknown impurities were detected.

Oxidation of testosterone propionate $(6 \boldsymbol{a})$. To a stirred solution of testosterone propionate (6a) (344 mg, $1 \mathrm{mmol}$ ) in DMSO at rt IBX was added $(2.24 \mathrm{~g}, 8 \mathrm{mmol})$. After heating at $85{ }^{\circ} \mathrm{C}$ for $22 \mathrm{~h}$, the reaction mixture was poured into EtOAc $(10 \mathrm{~mL})$ and the insoluble material was washed with EtOAc. The combined organic phases were washed with $5 \%$ aqueous $\mathrm{NaHCO}_{3}$ dried and evaporated to yield 9a as a yellow solid, pure by TLC (273 mg, 80\%), that was used in the next step without further purification.

The transformation of 9a $(273 \mathrm{mg}, 0.8 \mathrm{mmol})$ into $9 \mathbf{b}$ (226 mg, 99\%) was carried out as described above.

To a stirred solution of $\mathbf{9 b}(189 \mathrm{mg})$ in DMSO $(5 \mathrm{~mL})$ at rt IBX (280 mg, $1 \mathrm{mmol}$ ) was added. After $18 \mathrm{~h}$ of stirring the yellow solution was poured into EtOAc $(30 \mathrm{~mL})$ and the organic phase was washed with $5 \%$ aqueous $\mathrm{NaHCO}_{3}$ and brine, dried and evaporated to yield 8 (167 $\mathrm{mg}, 88 \%$ ). This product was used for the oxidation to $\mathbf{1}$, without further purification.

\section{Acknowledgements}

We thank Consejo Nacional de Investigaciones Científicas y Técnicas (CONICET), Universidad Nacional de Rosario (UNR) and Agencia Nacional de Promoción Científica y Tecnológica for financial support.

\section{References}

1. Tavares da Silva, E.J.; Sá e Melo, M.L.; Campos Neves, A.S.; Paixao, J.A.; Andradde, L.C.R., Almeida, M.-J.M.; Costa, M.M.R.; J. Chem. Soc., Perkin Trans. 1 1997, 3487 and references therein
2. Fried, J.; Thoma, R.W.; Klingsberg, A.; J. Am. Chem. Soc. 1953, 75,5764

3. Lednicer, D.; Mitscher, L.A.; The Organic Chemistry of Drug Synthesis, John-Wiley \& Sons: New York, 1980, vol. 2, p. 160 and references cited therein.

4. Djerassi, C.; Scholz, C.R.; J. Org. Chem. 1948, 13, 697.

5. Ringold, H.J.; Rosenkranz, G.; Sondheimer, F.; J. Org. Chem. 1956, 21, 239

6. Luzzio, F.A.; Fitch, R.W.; Moore, W.J.; Mudd, K.J.; J. Chem. Educ. 1999, 76, 974.

7. Turner, A.B.; Ringold, H.J.; J. Chem. Soc. (C) 1967, 1720.

8. Larock, R.C.; Comprehensive Organic Transformations, VCH: New York, 1989, p. 149.

9. Ito, Y.; Hirao, T.; Saegusa, T.; J. Org. Chem. 1978, 43, 1011.

10. Mino, T.; Masuda, S.; Nishio, M.; Yamashita, M.; J. Org. Chem. 1997, 62, 2633.

11. Nicolaou, K.C.; Montagnon, T.; Baran, P.S.; Zhong, Y.-L.; J. Am. Chem. Soc. 2002, 124, 2245.

12. Dess, D.B.; Martin, J.C.; J. Am. Chem. Soc. 1991, 113, 7277.

13. Frigerio, M.; Santagostino, M.; Sputore, S.; J. Org. Chem. 1999, 64, 4537.

14. All the oxidation reactions using IBX were run in DMSO, a solvent with low order of toxicity. We did not use mixtures of DMSO and fluorobenzene as recommended by Nicolaou et al. in ref. 11.

15. Mülbaier, M.; Giannis, A.; Angew. Chem. Int. Ed. 2001, 40, 4393; Sorg, G.; Mengel, A.; Jungand, G.; Rademann, J.; Angew. Chem. Int. Ed. 2001, 40, 4395; Togo, H.; Sakuratani, K.; Synlett 2002, 1966.

16. The Merck Index, $10^{\text {th }}$ ed., Merck and Co., Inc.: Rahway, 1983, p. 8996

17. The Merck Index, $10^{\text {th }}$ ed., Merck and Co., Inc.: Rahway, 1983, p. 666. 